\title{
Roasted Pearl Millet Flour (RoPMF) Improved the Mineral Composition of Beef Sausages
}

\author{
Joseph Yaro ${ }^{\mathrm{a}}$, Frederick Adzitey ${ }^{\mathrm{a}, \mathrm{b}}$, Nurul Huda ${ }^{\mathrm{c}, \mathrm{d}, *}$ \\ a Department of Animal Science, University for Development Studies, P. O. Box TL 1882, Tamale, Ghana \\ ${ }^{b}$ Department of Food Science and Technology, University for Development Studies, P. O. Box TL 1882, Tamale, Ghana \\ ${ }^{c}$ Faculty of Food Science and Nutrition, Universiti Malaysia Sabah, 88400, Kota Kinabalu, Sabah, Malaysia \\ ${ }^{d}$ Department of Food Science and Technology, Faculty of Agriculture, Universitas Sebelas Maret, Surakarta, Central Java, 57126, Indonesia \\ Corresponding author: *drnurulhuda@ums.edu.my
}

\begin{abstract}
Meat products which are cheaper and have better nutritional composition are crucial for reducing hunger and promoting good health and wellbeing of humans. This study investigated the nutritional, physicochemical, sensory, and formulation cost of beef sausages prepared using roasted pearl millet flour (RoPMF). A complete randomized design was used to assign roasted pearl millet flour (0\% RoPMF, 5\% RoPMF, 10\% RoPMF and 15\% RoPMF) to meats. Other ingredients were added in equal amounts. The official methods of analysis of the Association of Official Analytical Chemists and British Standard Institute procedures were used for mineral and sensory analysis, respectively. There were significant differences $(P<0.05)$ in the mineral composition of the beef sausages. The iron, magnesium and calcium contents of the RoPMF sausages were generally higher than the control (0\% RoPMF) sausages. The potassium contents of 5\% RoPMF and 15\% RoPMF sausages were similar $(\mathrm{P}>0.05)$ to the control. The 5\% RoPMF sausages had the highest zinc content of $35.29 \pm 0.18 \mathrm{mg} / \mathrm{kg}$. There were no significant differences $(P>0.05)$ in the sensory (color, flavor intensity, flavor liking, texture, tenderness, juiciness) scores and overall acceptability of the beef sausages. The ash, fat, carbohydrate, water holding capacity, and peroxide value of the beef sausages were not affected $(P>0.05)$ when RoPMF was used for the formulation. In general, the protein content of the RoPMF beef sausages was not affected negatively. The cost of producing a kilogram of beef sausages was GHS 31.50 (\$5.47), GHS 31.10 (\$5.40), GHS 30.70 (\$5.33), and GHS 30.30 (\$5.26) for 0\% RoPMF, 5\% RoPMF, 10\% RoPMF, and 15\% RoPMF beef sausages, respectively. It is concluded that the formulation of beef sausages with roasted pearl millet flour did not negatively affect the sensory characteristics of the sausages, but improved it mineral composition and reduced production cost.
\end{abstract}

Keywords - Beef sausages; meat; mineral composition; sensory analysis; roasted pearl millet flour.

Manuscript received 12 Nov. 2020; revised 10 Jan. 2021; accepted 1 Feb. 2021. Date of publication 30 Apr. 2021. IJASEIT is licensed under a Creative Commons Attribution-Share Alike 4.0 International License.

\section{INTRODUCTION}

The human population worldwide continues to increase and age yearly. The world's population was estimated to be 7.8 billion [1]. There was a percentage increase of $1.05 \%$ from 2019 to 2020 and $1.08 \%$ from 2018 to 2019 [1]. An increase in the human population requires the availability, accessibility, and affordability of foods with better nutrient composition [2]. Also, the aging population is sometimes accompanied by the consumption of foods with specific nutrients. Meat (e.g., beef) in the form of food contributes to humans' protein intake [3]. Besides that, meat contains other nutrients such as lipids (arachidonic, linolenic, linoleic, and oleic), minerals (zinc, calcium, potassium, and iron), vitamins (vitamin B12, vitamin B6, riboflavin, thiamin), some bioactive compounds, and small quantities of carbohydrates [3]-[5].
Despite the nutrient composition of meat, it is highly susceptible to spoilage initiated by microorganisms and enzymatic activities of the meat unless processed into a form that can be consumed or stored [6], [7]. Meat can be processed into products such as sausages, burgers, meatloaf, among others, to improve their palatability, increase their shelf life, and/or add value [8]-[11]. Various cereals (grains) like millet, sorghum, wheat, rice, rye, wheat, and corn can be used to extend meat products to improve their nutrient composition and to reduce cost [12], [13]. Food and Agriculture Organization [4] stated that meat processing results in the preservation and extension of shelf life, and improve tenderness and flavor of meat and meat products.

The ever-growing population and desire by people to improve their lives present them with many opportunities to spend much time working, leaving them with little time for 
food preparation [14]. This has resulted in an increasing desire for meat and meat products due to their convenience and the minimal processing required before consumption [15]. However, health-related issues like colorectal cancer, cardiovascular diseases, and diabetes associated with meat and meat products hamper their patronage and consumption [16]. The development of meat and meat products with better nutritional composition is essential to sustain the demand for such products. This can be achieved by incorporating foods or ingredients with the required nutrients into meat products.

Millet is a small-seeded cereal with better nutritional quality. The grain is widely consumed by millions of people worldwide [13] and ranked fourth among important tropical cereals [17]. It has been reported to be a versatile grain that is highly nutritious, non-acid, and non-glutinous food [18]. Millet contains many macronutrients and micronutrients, and rich in phytochemicals such as phytosterols, phenolic acids, and lignans [19], [20]. It is also a major source of dietary fiber [21]. Ragaee et al. [22] indicated that millet is superior or comparable to commonly consumed cereal grains such as rice and wheat.

The consumption of millet also has health-promoting effects. They protect against obesity, ischemic stroke, type II diabetes, breast cancer, heart disease, childhood asthma, among others [13], [23], [24]. Despite the nutritional and health benefits of millet, its potential as an extender in meat products is yet to be exploited. Therefore, this study aimed at determining the nutritional composition, physicochemical properties, sensory evaluation, and formulation cost of beef sausages incorporated with roasted pearl millet as an extender.

\section{MAterials AND METHOdS}

\section{A. Preparation of Roasted Pearl Millet Flour (RoPMF)}

Pearl millets were purchased from the local market and sieved to remove all debris. They were then washed with water three times to clean the grains. The grains were sundried for $8 \mathrm{~h}$ and roasted until even browning. Roasted millet grains were allowed to cool and subsequently milled into flour.

TABLE I

SAUSAGE FORMULATION USING ROASTED PEARL MILLET FLOUR (ROPMF)

\begin{tabular}{lllll}
\hline \multirow{2}{*}{ Ingredients } & \multicolumn{4}{c}{ Treatments } \\
\cline { 2 - 5 } & $\mathbf{0 \%}$ & $\mathbf{5 \%}$ & $\mathbf{1 0 \%}$ & $\mathbf{1 5 \%}$ \\
\hline Beef $(\mathrm{kg})$ & 2.00 & 1.90 & 1.80 & 1.70 \\
RoPMF (g) & 0 & 0.10 & 0.20 & 0.30 \\
Curing salt (g) & 0.03 & 0.03 & 0.03 & 0.03 \\
Adobo (g) & 0.002 & 0.002 & 0.002 & 0.002 \\
White pepper (g) & 0.004 & 0.004 & 0.004 & 0.004 \\
Black pepper (g) & 0.004 & 0.004 & 0.004 & 0.004 \\
Chilli pepper (g) & 0.001 & 0.001 & 0.001 & 0.001 \\
Phosphate (g) & 0.01 & 0.01 & 0.01 & 0.01 \\
Ice cubes (g) & 0.14 & 0.14 & 0.14 & 0.14 \\
Soy oil (ml) & 0.26 & 0.26 & 0.26 & 0.26 \\
\hline
\end{tabular}

\section{B. Formulation of Beef Sausages Using RoPMF}

RoPMF replaced minced beef at $0,5,10$, and $15 \%$ on a twokilogram basis. Spices and ice cubes were added in equal amounts, as shown in Table 1 . Beef samples were cut into smaller pieces and minced through a $5 \mathrm{~mm}$ mincer (Telleres Rammon, Spain). The minced beef was comminuted with spices using a bowl chopper (Telleres Rammon, Spain). Ice was added during comminution to maintain the temperature at $16{ }^{\circ} \mathrm{C}$ and to attain the desired consistency. The comminuted batter was transferred into a hydraulic stuffer (Telleres Rammon, Spain) and manually linked into the equal length of about $10 \mathrm{~cm}$. They were then smoked for $30 \mathrm{~min}$ at $105{ }^{\circ} \mathrm{C}$; after which, they were scalded for $20 \mathrm{~min}$ at $55^{\circ} \mathrm{C}$. The final beef sausages were cooled, packaged, and stored at $-18{ }^{\circ} \mathrm{C}$ for nutritional, sensory, and physicochemical analyses.

\section{Preparation and Sensory Evaluation of RoPMF Beef Sausages}

Frozen beef sausages were allowed to thaw at room temperature for $2 \mathrm{~h}$ and grilled in an electric oven (Turbofan Blue Seal, UK) for $45 \mathrm{~min}$ at a temperature of $105^{\circ} \mathrm{C}$. The grilled beef sausages were sliced into uniform sizes of $2 \mathrm{~cm}$ in length and wrapped in coded aluminum foil for sensory evaluation. Fifteen panelists were selected at random from the University for Development Studies and trained using British Standard Institute Guidelines [25] to constitute the taste panel. The products were presented to each of the panelists for independent evaluation for color, flavor intensity, flavor liking, tenderness, texture, taste, juiciness, and overall preference using a nine-point hedonic scale (e.g., 1: extremely like to 9: dislike extremely) as presented in supplementary data (sensory analysis outline).

\section{Proximate Composition of RoPMF Beef Sausages}

The proximate composition of the beef sausages was done according to the Association of Official Analytical Chemists [26]. The protein content was determined using the Kjeldahl apparatus (method 954.01). The fat content was determined using the Soxhlet apparatus (method 920.39). The ash content was determined using a furnace (method 942.09). The moisture content was determined using oven drying (method 930.15), and the carbohydrate content was calculated using the following equation: Total carbohydrate $=100-(\%$ moisture $+\%$ fat $+\%$ protein $+\%$ ash). All analyses were carried out in triplicates.

\section{E. Mineral Analysis of RoPMF Beef Sausages}

This was done using a slightly modified method of Adua et al. [27]. Ten (10) $\mathrm{ml}$ concentrated $\mathrm{H}_{2} \mathrm{SO}_{4}$ and $2 \mathrm{ml}$ perchloric acid were added to $1 \mathrm{~g}$ of beef sausage sample in a digestion tube. The mixture was heated at a temperature of $350{ }^{\circ} \mathrm{C}$ until the solution turned clear. The solution was allowed to cool, and $2 \mathrm{ml}$ of hydrogen peroxide was added. After which, distilled water was added to make up to $50 \mathrm{ml}$ mark. The solution was measured using an Atomic Absorption Spectrometer (AAS model novAA 400 P, Analytik Jena AG, Germany) to determine the various nutrients. The instrumental conditions used to measure the multiple minerals are shown as supplementary data (instrumental requirements for measuring elements).

\section{F. pH Measurements of RoPMF Beef Sausages}

$\mathrm{pH}$ was measured using a digital $\mathrm{pH}$ meter (Crison Basic 20 , Spain) in triplicates. Before the test, the $\mathrm{pH}$ meter was calibrated with two buffers of $\mathrm{pH} 4.01$ and 7.00. Ten grams $(10 \mathrm{~g})$ of each sausage was ground in mortar and pestle and homogenized with $10 \mathrm{ml}$ of distilled. After which, the $\mathrm{pH}$ values were measured using the $\mathrm{pH}$ meter (Crison Basic 20, Alella, Spain). 


\section{G. Water Holding Capacity (WHC) of RoPMF Beef Sausages}

The WHC was determined using a slightly modified procedure of Heywood et al. [28]. The analysis was carried out in triplicates. Briefly, $2.5 \mathrm{~g}$ of each sample was placed in pre-weighed $50 \mathrm{ml}$ centrifuge tubes, and $10 \mathrm{ml}$ distilled water was added. They were mixed thoroughly, allowed to stand for $30 \mathrm{~min}$ at room temperature, and centrifuge at $3700 \mathrm{rpm}$ for 30 min using Hettich ROTOFIX 32A Centrifuge, Germany. After centrifugation, the supernatant was decanted, and the sample weight taken. WHC was calculated according to the following equation:

$\mathrm{WHC} / \mathrm{g}=\mathrm{Dw}-\mathrm{Sw}$

$\mathrm{WHC}(\%)=\mathrm{Dw}-\mathrm{Sw} / \mathrm{Sw} \times 100$

Where: Dw is the decant weight of the sample after centrifugation, $\mathrm{Sw}$ is the sample weight.

\section{H. Cooking Loss (CL) of RoPMF Beef Sausages}

Cooking loss of the beef sausages was determined according to Lee et al. [29]. Three fingers from each treatment were weighed separately and then grilled in an oven at $150{ }^{\circ} \mathrm{C}$ for about $45 \mathrm{~min}$ to a core temperature of $70{ }^{\circ} \mathrm{C}$. Samples were allowed to cool at room temperature and reweighed. Cooking losses were determined by the weight difference between raw and cooked/grilled sausages using the following equation:

Cooking loss $=$ Raw weight - Cooked weight

Cooking loss $\%=\mathrm{Wr}-\mathrm{Wc} / \mathrm{Wr} \times 100$

Where: $\mathrm{Wr}=$ weight of raw sausage, $\mathrm{Wc}=$ weight of cooked sausage.

\section{Peroxide Value Determination of RoPMF Beef Sausages}

Peroxide value was determined using a modified method of Abu et al. [9] and Adua et al. [27]. Briefly, $10 \mathrm{~g}$ of the beef sausage was added to $30 \mathrm{ml}$ hexane in a $100 \mathrm{ml}$ Erlenmeyer flask and shaken at $250 \mathrm{rpm}$ for $60 \mathrm{~min}$. It was then transferred into a $50 \mathrm{ml}$ falcon tube, and centrifuge at $3000 \mathrm{rpm}$ for $5 \mathrm{~min}$. The supernatant was evaporated using an evaporator. The residues were evaporated twice, first extracted with $5 \mathrm{ml}$ acetic acid-chloroform solution and $10 \mathrm{ml}$ of additional acetic acid-chloroform. The extracted samples were transferred into a $100 \mathrm{ml}$ Erlenmeyer flask and were added with $1 \mathrm{ml}$ of saturated potassium iodide solution. After which, $5 \mathrm{ml}$ of $1 \%$ starch soluble solution was added, and the resulting mixture was titrated against $0.01 \mathrm{~N}$ sodium thiosulfate solution. The endpoint was identified by transforming a cyan or orange color to a transparent or white color. A blank test was used for calibration. The peroxide value was calculated using the following equation:

Peroxide value $(\mathrm{mEq} / \mathrm{kg})=\left(\mathrm{V}_{1}-\mathrm{V}_{0}\right) \times \mathrm{N} \times 1000 / \mathrm{S}$

Where: $\mathrm{V}_{1}=$ titre value of sample, $\mathrm{V}_{0}=$ titre value of blank, $\mathrm{S}=$ weight of sample, $\mathrm{N}=$ normality of sodium thiosulfate.

\section{J. Cost of Production of RoPMF Beef Sausages}

The cost of a kilogram of beef and millet, and the cost of processing each kilogram millet were determined. The cost of each percentage inclusion level $(0,5,10$, and $15 \%)$ was determined as a proportion of the respective kilogram cost. The cost of spices, curing salt, and ice cubes for processing a kilogram of beef sausage were equal across treatments.

\section{K. Data Analysis}

The data obtained were analyzed using one-way ANOVA in Genstat Discovery 4th edition. Significant differences were separated at $5 \%$ using Tukey studentized range test. [18].

\section{RESULT AND DISCUSSION}

\section{A. Proximate Composition of Roasted Pearl Millet Flour (RoPMF) Beef Sausages}

The results for the proximate composition of the RoPMF beef sausages are shown in Table 2. There were no significant differences $(\mathrm{P}>0.05)$ in the ash, fat, and carbohydrate contents of the beef sausages. The ash, fat, and carbohydrate contents ranged from $4.47 \pm 0.57$ to $5.94 \pm 0.92 \%, 5.53 \pm 3.22$ to $8.97 \pm 3.99 \%$, and $2.77 \pm 1.70$ to $6.76 \pm 3.42 \%$, respectively. The moisture content of the control beef sausages $(0 \%$ RoPMF beef sausages) was significantly higher $(\mathrm{P}<0.05)$ than the 5 , 10 , and $15 \%$ RoPMF beef sausages. Interestingly, the protein content was highest in the $15 \%$ RoPMF beef sausages and least in the 5\% RoPMF beef sausages.

TABLE II

Proximate Compositions Of Roasted Pearl Millet Flour Beef Sausages (Ropmfs)

\begin{tabular}{llllll}
\hline \multirow{2}{*}{ Treatment (\%) } & \multicolumn{5}{c}{ Parameters } \\
\cline { 2 - 6 } & Moisture (\%) & Ash (\%) & Fat (\%) & Protein (\%) & Carbohydrate (\%) \\
\hline 0\% RoPMFS (Control) & $68.42 \pm 0.43^{\mathrm{a}}$ & $4.47 \pm 0.57$ & $5.53 \pm 3.22$ & $18.81 \pm 1.50^{\mathrm{ab}}$ & $2.77 \pm 1.70$ \\
$5 \%$ RoPMFS & $67.05 \pm 0.37^{\mathrm{b}}$ & $4.49 \pm 1.02$ & $8.00 \pm 2.71$ & $15.69 \pm 0.44^{\mathrm{b}}$ & $4.77 \pm 3.04$ \\
$10 \%$ RoPMFS & $64.11 \pm 0.39^{\mathrm{c}}$ & $4.77 \pm 0.87$ & $7.73 \pm 1.18$ & $16.62 \pm 1.32^{\mathrm{ab}}$ & $6.76 \pm 3.42$ \\
$15 \%$ RoPMFS & $61.07 \pm 0.40^{\mathrm{d}}$ & $5.94 \pm 0.92$ & $8.97 \pm 3.99$ & $20.02 \pm 2.55^{\mathrm{a}}$ & $4.01 \pm 3.32$ \\
$\mathrm{P}-$ value & $<0.001$ & 0.199 & 0.566 & 0.041 & 0.456 \\
\hline
\end{tabular}

Values are means \pm standard deviation. Values with different superscripts under the same column are significantly different $(\mathrm{P}<0.05)$

The development of food products brings diversity and increases the choice of food for consumption. This diversity also promotes sustainability by helping to reduce hunger, promoting good health and poverty alleviation by direct or indirect employment for those involved in the handling of meat and meat products. Foods from animal sources are very important sources of protein and other nutrients. The demand for foods that require minimum processing before consumption has contributed to the craving for meat and meat products. The good taste of meat products has also aggravated it. Ehr et al. [30] reported that sausage is the most appetizing and common processed meat product. The Chorizo sausage 
has been shown to provide $13.6 \mathrm{~g}$ of protein, $25.9 \mathrm{~g}$ of total fat, $788 \mathrm{mg}$ of sodium, $308 \mathrm{mg}$ of potassium, $20 \mathrm{mg}$ of magnesium, $19 \mathrm{mg}$ of calcium, $1.6 \mathrm{mg}$ of zinc, $1.1 \mathrm{mg}$ iron, and $5.4 \mathrm{mg}$ of niacin [31].

Meat products with better nutrient composition are brought about by incorporating ingredients, raw materials, or foods that have required nutrients of interest. Millet is one of the foods that can be added to meat products to improve its nutrient composition and to promote good health upon consumption. It is an important crop, especially in Africa and Asia [32]. It is significantly rich in phytochemicals and micronutrients [33]. It is also a good source of minerals, soluble and insoluble dietary fiber, resistant starch, and antioxidants [22]. The low glycemic index of millet makes it a good grain for diabetic patients and less likely to trigger high blood pressure $[13,22]$. The importance of millet can only be unraveled when raw millets are processed into forms that are edible. One of the ways of processing millet to make it ready for consumption is by roasting.

In the current study, roasted pearl millet flour (RoPMF) was incorporated into beef sausages to influence its nutritional, physicochemical and sensory properties and the cost of production. The usage of RoPMF did not influence the ash, fat and carbohydrate contents. Moisture content decreased with the increasing inclusion level of RoPMF. Agnihotri and Pall [34] reported that the moisture content of sausages is about $66.77 \%$, which is similar to the findings of this study. Moisture improves the juiciness of meat products [35], [36]. However, the high moisture content of the $0 \%$ RoPMF beef sausages did not reflect in the juiciness of the RoPMF beef sausages as judged by the panelists. The addition of RoPMF to beef sausages did not negatively affect its protein content. Contrarily, the protein contents of sausages were reduced when maize flours were used as an extender [37].

\section{B. Mineral Composition of RoPMF Beef Sausages}

Table 3 shows the mineral composition of the RoPMF beef sausages. There were significant differences $(\mathrm{P}<0.05)$ in the iron, magnesium, calcium, potassium, and zinc contents of the beef sausages. The iron, magnesium, and calcium contents were higher $(\mathrm{P}<0.05)$ in the 5, 10, and 15\% RoPMF beef sausages than the control beef sausages. Potassium content was the least $(\mathrm{P}<0.05)$ in the $10 \%$ RoPMF beef sausages. The zinc content of the 5\% RoPMF beef sausages was higher $(\mathrm{P}<0.05)$ than the rest of the beef sausages.

TABLE III

MINERAL COMPOSITIONS OF ROASTED PEARL MILLET FLOUR BEEF SAUSAGES (ROPMFS)

\begin{tabular}{llllll}
\hline \multirow{2}{*}{ Treatment (\%) } & \multicolumn{5}{c}{ Parameters } \\
\cline { 2 - 6 } & Iron $(\mathbf{m g} / \mathbf{k g})$ & Magnesium $(\mathbf{m g} / \mathbf{k g})$ & Calcium $(\mathbf{m g} / \mathbf{k g})$ & Potassium $(\mathbf{m g} / \mathbf{k g})$ & $\mathbf{Z i n c}(\mathbf{m g} / \mathbf{k g})$ \\
\hline $0 \%$ RoPMFS (Control) & $26.73 \pm 0.55^{\mathrm{c}}$ & $594.99 \pm 0.94^{\mathrm{d}}$ & $64.26 \pm 0.12^{\mathrm{d}}$ & $1137.46 \pm 1.24^{\mathrm{a}}$ & $33.96 \pm 0.07^{\mathrm{b}}$ \\
$5 \%$ RoPMFS & $54.99 \pm 0.13^{\mathrm{a}}$ & $753.09 \pm 1.10^{\mathrm{c}}$ & $93.67 \pm 0.37^{\mathrm{b}}$ & $1125.05 \pm 5.34^{\mathrm{a}}$ & $35.29 \pm 0.18^{\mathrm{a}}$ \\
$10 \%$ RoPMFS & $44.55 \pm 0.75^{\mathrm{b}}$ & $780.38 \pm 0.39^{\mathrm{b}}$ & $98.84 \pm 0.15^{\mathrm{a}}$ & $1075.07 \pm 2.84^{\mathrm{b}}$ & $32.20 \pm 0.01^{\mathrm{c}}$ \\
$15 \%$ RoPMFS & $56.15 \pm 0.63^{\mathrm{a}}$ & $842.89 \pm 1.82^{\mathrm{a}}$ & $91.22 \pm 0.13^{\mathrm{c}}$ & $1132.90 \pm 2.18^{\mathrm{a}}$ & $32.25 \pm 0.10^{\mathrm{c}}$ \\
$\mathrm{P}-$ value & $<0.001$ & $<0.001$ & $<0.001$ & $<0.001$ & $<0.001$ \\
\hline \multicolumn{2}{c}{ Values are means \pm standard deviation. Values with different superscripts under the same column are significantly $(\mathrm{P}<0.05)$ different. }
\end{tabular}

The 5, 10, and 15\% RoPMF beef sausages contained a significantly higher amount of minerals than the control sausages. Iron, magnesium, and calcium contents of 5, 10, and $15 \%$ RoPMF beef sausages were considerably better than the control beef sausages. This implies that the RoPMF beef sausages are rich sources of iron, magnesium, and calcium. These minerals are needed in the human body to form strong bones, boost the immune system, blood glucose regulation, blood pressure regulation, normal functioning of nerve and muscle, and transfer of oxygen from the lungs to tissues [3840]. Behailu and Abebe [41] used soybean and finger millet flour to prepare beef sausages and reported that the calcium and zinc contents ranged from $1.22 \pm 0.02$ to $1.87 \pm 0.14$ and $0.06 \pm 0.09$ to $0.09 \pm 0.03$, respectively. This study found higher levels of calcium and zinc than that of Behailu and Abebe [41]. Also, lower levels of iron, magnesium, calcium, potassium, and zinc were reported by Adua et al. [27] in Citrullus vulgaris ('Niri') extended beef sausages.

\section{Physicochemical Characteristics of RoPMF Beef Sausages}

The $\mathrm{pH}$, water holding capacity, and cooking loss of the RoPMF beef sausages is presented in Table 4 . There were significant differences $(\mathrm{P}<0.05)$ in the $\mathrm{pH}$ and cooking loss of the beef sausages. The $\mathrm{pH}$ ranged from $5.94 \pm 0.02$ for control beef sausages to $6.00 \pm 0.02$ for $15 \%$ RoPMF beef sausages. The cooking loss ranged from $13.32 \pm 0.32 \%$ for $10 \%$ RoPMF beef sausages to $26.74 \pm 1.18 \%$ for $5 \%$ RoPMF beef sausages. The water holding capacity ranged from $1.12 \pm 0.07 \mathrm{ml} / \mathrm{g}$ for $10 \%$ RoPMF beef sausages to $1.25 \pm 0.13 \mathrm{ml} / \mathrm{g}$ for $15 \%$ RoPMF beef sausages. The water holding capacity of the beef sausages did not differ significantly $(\mathrm{P}>0.05)$ from each other.

TABLE IV

Physicochemical Properties Of Roasted Pearl Millet Flour Beef SAUSAGES (ROPMFS)

\begin{tabular}{lccc}
\hline \multirow{2}{*}{$\begin{array}{l}\text { Treatment } \\
(\%)\end{array}$} & \multicolumn{3}{c}{ Parameters } \\
\cline { 2 - 4 } & $\mathbf{p H}$ & Cooking loss (\%) & WHC (ml/g) \\
\hline $\begin{array}{l}\text { 0\% RoPMFS } \\
\text { (Control) }\end{array}$ & $5.94 \pm 0.02^{\mathrm{c}}$ & $25.00 \pm 0.41^{\mathrm{a}}$ & $1.24 \pm 0.14$ \\
$5 \%$ RoPMFS & $5.95 \pm 0.00^{\mathrm{bc}}$ & $26.74 \pm 1.18^{\mathrm{a}}$ & $1.16 \pm 0.12$ \\
$10 \%$ & $5.98 \pm 0.01^{\mathrm{ab}}$ & $13.32 \pm 0.32^{\mathrm{c}}$ & $1.12 \pm 0.07$ \\
RoPMFS & & $21.48 \pm 1.28^{\mathrm{b}}$ & $1.25 \pm 0.13$ \\
$15 \%$ & $6.00 \pm 0.02^{\mathrm{a}}$ & $<0.001$ & 0.555 \\
RoPMFS & 0.003 & & \\
P - value & &
\end{tabular}

Values are means \pm standard deviation. Values with different superscripts under the same column are significantly $(\mathrm{P}<0.05)$ different.

The peroxide value of the roasted pearl millet (RoPMF) beef sausages is shown in Figure 1. There were no significant 
differences $(\mathrm{P}>0.05)$ in the peroxide value of the beef sausages during the storage period. The peroxide values ranged from $2.84-3.59 \mathrm{meq} / \mathrm{kg}, 2.41-3.80 \mathrm{meq} / \mathrm{kg}$ and $2.21-$ $3.47 \mathrm{meq} / \mathrm{kg}$ in week 1 , week 2 and week 3 , respectively (Supplementary data- peroxide value of RoPMFS).

The $\mathrm{pH}$ increased as the inclusion level of RoPMF increased in the sausages. However, they were within the normal $\mathrm{pH}$ range of 5.94-6.00 for beef sausages as reported by Ibrahim [42]. $\mathrm{pH}$ influences the growth of microorganisms and the shelf life of meat and meat products [4].

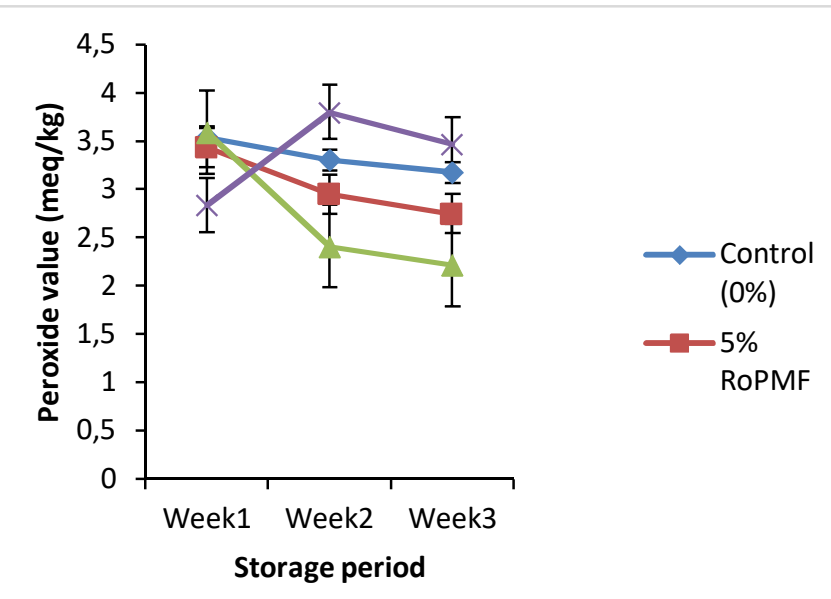

Fig.1 Peroxide value of roasted pearl millet flour (RoPMF) beef sausages

The high acidity of the beef sausages makes them require refrigerated storage to increase their shelf life. Cooking loss decreased with increasing level of RoPMF in beef sausages, implying that less weight will be lost during cooking of
RoPMF beef sausages. Nonetheless, the water holding capacity was not influenced by the use of RoPMF in beef sausages. The percentage cooking loss was similar to the findings of Teye et al. [43], who stated $24.50-27.00 \mathrm{~g}$ in weight loss of extended beef and ham burgers. The peroxide values found in this study were below the maximum permissible limit of $25 \mathrm{meq} / \mathrm{kg}$ of oxygen $/ \mathrm{kg}$ of products [44]. The sausages incorporated with test materials had lower values due to the presence of roasted pearl millet flour, which served as an antioxidant to stop lipid oxidation. Millets have been reported to have higher free radical quenching potential $[22,45]$.

\section{Sensory Evaluation of Roasted Pearl Millet (RoPMF) Beef Sausages}

Table 5 shows the sensory characteristics of the RoPMF beef sausages. There were no significant differences $(\mathrm{P}>0.05)$ in the color, flavor intensity, flavor liking, texture, tenderness, juiciness, and overall liking of the beef sausages. The use of RoMPF to formulate beef sausages did not affect the color, flavor intensity, flavor liking, texture, tenderness, and juiciness, and overall liking of the sausages. The beef sausages were described as intermediate to slightly pale for color, intermediate to slightly strong for flavor intensity, like slightly for flavor liking, intermediate to slightly smooth for texture, intermediate to slightly tender for tenderness, intermediate to slightly juicy for juiciness, and like slightly to like moderately for overall liking by the sensory panelist. Teye et al. [46] stated that the inclusion of cowpea flours up to $10 \%$ in comminuted beef and pork frankfurter-type sausages gave positive outcomes in sensory and yield of products.

TABLE V

Sensor y Evaluation Of Roasted Pearl Millet Flour Beef Sausages (Ropmfs)

\begin{tabular}{llllllll}
\hline Treatment (\%) & Color & Flavor intensity & Flavor liking & Texture & Tenderness & Juiciness & Overall liking \\
\hline 0 & $5.67 \pm 2.13$ & $6.00 \pm 1.69$ & $6.47 \pm 1.81$ & $4.87 \pm 1.77$ & $4.93 \pm 2.05$ & $5.67 \pm 2.02$ & $6.20 \pm 1.90$ \\
5 & $6.47 \pm 1.06$ & $6.00 \pm 1.36$ & $6.20 \pm 2.15$ & $5.60 \pm 1.64$ & $6.00 \pm 1.46$ & $5.33 \pm 1.68$ & $7.00 \pm 1.00$ \\
10 & $5.40 \pm 1.60$ & $6.00 \pm 1.51$ & $6.13 \pm 2.03$ & $6.33 \pm 1.50$ & $6.00 \pm 1.41$ & $4.87 \pm 1.41$ & $6.13 \pm 2.03$ \\
15 & $5.40 \pm 1.84$ & $5.20 \pm 0.86$ & $6.20 \pm 1.32$ & $5.47 \pm 1.64$ & $5.80 \pm 1.70$ & $5.47 \pm 1.89$ & $6.67 \pm 1.45$ \\
$\mathrm{P}-$ value & 0.26 & 0.153 & 0.779 & 0.124 & 0.492 & 0.332 & 0.629 \\
\hline
\end{tabular}

\section{E. Formulation Cost of Roasted Pearl Millet (RoPMF) Beef Sausages}

The formulation cost of the RoPMF beef sausages is shown in Table 6. The formulation cost in Ghana cedis (GHS) of the RoPMF beef sausages for the control $(0 \%), 5 \%, 10 \%$, and $15 \%$ incorporation levels were 31.50 (\$5.47), 31.10 (\$5.40), 30.70 (\$5.33), and 30.3 (\$5.26), respectively. The formulation costs of 5,10 , and $15 \%$ RoPMF beef sausages were lower than the $0 \%$ RoPMF (control) beef sausage. The reason being that the cost of 5,10 , or $15 \%$ lean beef cost more than the same percentage cost of pearl millet on a kilogram basis. This means that the inclusion of RoPMF in beef sausages could reduce the cost of production, making the products more affordable compared to the control. This is supported by Malav et al. [47], who stated that the high cost of meat products limits its regular usage by the average income earner due to the expensive nature of lean meat.
TABLE VI

Formulation Cost Of Roasted Pearl Millet Flour Beef Sausages (ROPMFS)

\begin{tabular}{lllllll}
\hline Ingredient & & & & & \\
& & & & & & \\
Minced beef & 26 & 26 & 24.7 & 23.4 & 22.1 \\
Pearl millet & 5 & - & 0.25 & 0.5 & 0.75 \\
Milling & 2 & - & 0.1 & 0.2 & 0.3 \\
Water for & 1 & - & 0.05 & 0.1 & 0.15 \\
processing millet & 5 & - & 0.25 & 0.5 & 0.75 \\
Roasting of millet & 5 & 0.7 & 0.7 & 0.7 & 0.7 \\
Spice mix & 0.5 & 0.5 & 0.5 & 0.5 & 0.5 \\
Curing salt & 0.5 & 0.8 & 0.8 & 0.8 & 0.8 \\
Soy oil & 0.8 & 3 & 3 & 3 & 3 \\
Casing & 3 & 0.5 & 0.5 & 0.5 & 0.5 \\
Ice cube & 0.5 & - & 0.25 & 0.5 & 0.75 \\
Transportation & 5 & 31.5 & 31.1 & 30.7 & 30.3 \\
Total cost (GHS) & & & & & \\
\hline
\end{tabular}




\section{CONCLUSION}

We conclude that the incorporation of roasted pearl millet (RoPMF) in beef sausages generally improved the mineral contents of the sausages. Cooking lost was lowest for the $10 \%$ RoPMF beef sausages. The $\mathrm{pH}$ was lowest for the $0 \%$ and $5 \%$ RoPMF beef sausages. The addition of RoPMF to beef sausages did not affect the sensory characteristics, water holding capacity, and peroxide value of the beef sausages. The ash, fat, and carbohydrate contents were also not affected by the use of RoPMF for beef sausages. Formulation of beef sausages with RoPMF reduced the cost of production. Further research should be conducted to evaluate the microbial and phytochemical properties of roasted pearl flour beef sausages.

\section{ACKNOWLEDGMENT}

The authors are grateful to the University for Development Studies for allowing them to use the Meat Unit and Spanish Laboratory, Nyankpala Campus for sausage preparation, proximate composition and physicochemical analysis. Central Laboratory of the Kwame Nkrumah University of Science and Technology, Kumasi is also acknowledged for the analysis for mineral contents of the sausages. Grant for publication fee was by Universiti Malaysia Sabah, Jalan UMS, 88400, Kota Kinabalu, Sabah, Malaysia.

\section{REFERENCES}

[1] WorldMeter, "Current world population". [Online]. Available: https://www.worldometers .info/world-population/\#: :text=7.8\%20B illion $\% 20(2020)$,currently\%20living) $\% 20$ of $\% 20$ the $\% 20$ world, (accessed on 23/08/2020), 2020.

[2] A. Herforth, and S. Ahmed, "The food environment, its effects on dietary consumption, and potential for measurement within agriculture-nutrition interventions'. Food Sec. vol. 7, pp. 505-520, 2015.

[3] Food and Agriculture Organization, "Chapter 3 - Meat and health Meat consumption role of meat in the diets', [Online]. Available: http://www.fao.org/3/t0562e/t0562e05.htm, (accessed on 23/08/2020), 2020 .

[4] Food and Agriculture Organization, " Meat processing technology for small to medium scale producers". [Online]. Available: http://www.fao.org/docrep/010/ai407e/ai407e00.htm_, (accessed on 23/08/2020), 2007.

[5] R.S. Ahmad, A. Imran, and M.B. Hussain, "Nutritional composition of meat". [Online]. Available: https://www. intechopen.com/books/meat-science-and-nutrition/nutritionalcomposition-of-meat, (accessed on 23/08/2020), 2018.

[6] I.S. Boziaris, and F.F. Parlapani, "Specific spoilage organisms (SSOs) in fish'. In A. Bevilacqua, M.R.bCorbo, M. Sinigaglia, (Eds.), The microbiological quality of food. Duxford, UK: Woodhead Publishing, 2017.

[7] O.A. Odeyemi, O.O. Alegbeleye, M. Strateva, and Stratev, D. "Understanding spoilage microbial community and spoilage mechanisms in foods of animal origin". Compr. Rev. Food Sci. Food Saf. Vol. 19, pp. 311-331, 2020.

[8] R.N. Ossom, F. Adzitey, and G.A. Teye, "The effect of higher levels of egg albumen as binder in beef burger'. J. Food Res Technol. Vol. 4, pp. 16-21, 2016.

[9] A. Abu, G.A. Teye, and F. Adzitey, "Effects of sweet basil (Ocimum basilicum) leaf powder on the sensory and nutritional qualities of beef and frankfurter sausages". UDS Int. J. Develop. vol. 6, pp. 84-91, 2019.

[10] E.A. Adua, F. Adzitey, G.A.Teye, and A. Abu, "Nutritional composition and sensory properties of raw and roasted "Niri" (Citrullus vulgaris) puree extended beef sausages". Ghana J. Sci. Technol. Develop. vol. 7, pp. 1-11, 2020a.

[11] R.N. Ossom, F. Adzitey, G.A. Teye, A. Abu, F.K. Amagloh, "Sensory and nutritional qualities of beef sausages prepared with sweet potato puree as extender'’. Nig. J. Anim. Sci. 22, vol. pp. 338-348, 2020.
[12] Y. Iqra, "Cereal grain health benefits as a functional food". [Online] Available: https://www.newfoodmagazine.com/article/74005/cerealgrain-functional-food/ (accessed on 23/08/2020), 2017.

[13] A. Lang, "What is millet? Nutrition, benefits, and more"'. [Online]. Available: https://www.healthline.com/nutrition/what-is-millet (accessed on 23/08/2020), 2020.

[14] M. Amir, V.M. Marzieh, B. Homa, Monire, A.B. "Considering the physicochemical and sensorial properties of Momtaze hamburgers containing lentil and chickpea seed flour', J. Nutrit. Food Sci. Res. vol. 2, pp. 55-62, 2015.

[15] R.I. Stubbs, J.B. Morgan, K.F. Ray, and H.G. Dolezal, "Effect of supplemental vitamin E on color and case life of top lion steaks and ground chuck patties modified atmosphere case-ready retail packaging systems"'. Meat Sci. vol. 61, pp. 1-5, 2002.

[16] R.E. Battaglia, B. Baumer, B. Conrad, R. Darioli, A. Schmid, U. Keller, "Health risks associated with meat consumption: A review of epidemiological studies'’. Int. J. Vitam. Nutr. Res. vol. 85, pp. 70-80, 2015.

[17] S.M. Ismail, "Optimizing productivity and irrigation water use efficiency of pearl millet as a forage crop in arid regions under different irrigation methods and stress". Afr. J. Agric. Res. vol. 7, pp. 2509-2518, 2012.

[18] T.K. Hrideek, and K.U.K. Nampoothiri, "Millets as an integral part of nutritional diet in India. In examining the development, regulation, and consumption of functional foods". IGI Global, pp. 83-108, 2017,.

[19] F. Shahidi, and Chandrasekara, A. "Millet grain phenolics and their role in disease risk reduction and health promotion: A review'. $J$. Funct. Foods, vol. 5, pp. 570-581, 2013.

[20] M. Muthamilarasan, A. Dhaka, R. Yadav, and M. Prasad, "Exploration of millet models for developing nutrient rich graminaceous crops'. Plant Sci. vol. 242, pp. 89-97, 2016.

[21] Z. Izadi, A. Nasirpour, M. Izadi, and T. Izadi, "Reducing blood cholesterol by a healthy diet', Int. Food Res. J. vol. 19, pp. 29-37, 2012.

[22] S. Ragaee, E.M. Abdel-Aal, and M. Noaman, "Antioxidant activity and nutrient composition of selected cereals for food use". Food Chem. vol. 98, pp. 32-38, 2006.

[23] Y.Y. Choi, K. Osada, Y. Ito, T. Nagaswa, M.R. Choi, and N. Nishizawa, "Effects of dietary protein of Korean foxtail millet on plasma adiponectin, HDL-cholesterol, and insulin levels in genetically type 2 diabetic mice“". Bios. Biotechnol. Biochem. vol. 69, pp. 31-37, 2005.

[24] J.E. Cade, Berley, and D.C. Greenwood, "Dietary fibre and risk of breast cancer in the UK women's cohort study'. Int. J. Epidemiol. vol. 36, pp. 431-438, 2007.

[25] British Standard Institution, "Assessors for sensory analysis. Guide to selection, training and monitoring of selected assessors". British standard institution London, United Kingdom, 1993.

[26] Association of Official Analytical Chemists (AOAC), "Methods of analysis of AOAC International'. 17th ed.; AOAC International: Gaithersburg, MD, USA, 2000.

[27] E.A. Adua, F. Adzitey, and N. Huda, "Nutritional composition, physiochemical analysis, sensory properties and economics of raw and roasted "niri" (Citrullus vulgaris) chaff extended beef sausages". $J$. Anim. Health Prod. vol. 8, pp. 212-220, 2020b.

[28] A.A. Heywood, D.J. Myers, T.B. Bailey, and L.A. Johnson, "Functional properties of low-fat soy flour produced by an extrusionexpelling system'. J. Amer. Oil Chem. Soc. vol. 79, pp. 1249-1253, 2002.

[29] M.A. Lee, D.J. Han, J.Y. Jeong, J.H. Choi, Y.S. Choi, and H.Y. Kim, "Effect of kimchi powder level and drying methods on quality characteristics of breakfast sausage". Meat Sci. vol. 80, pp. 708-714, 2008 ,

[30] I.J. Ehr, T.L. Tronsky, D.R. Rice, D.M. Kinsman, and C. Faustman, "Home sausage making", 2nd Edition. Department of Animal Science, University of Connecticut, USA. pp. 2-13, 2016.

[31] Anonymous, "Nutritional elements in sausage"'. [Online]. Available: https://italianbarrel.com/is-sausage-healthy-to-eat/\#: :text= According\%20to\%20USDA\%20Guidelines\%20a,and\%20minerals \% 20in\%20lesser\%20quantities (accessed on 23/08/2020), 2020.

[32] C.M. McDonough, L.W. Rooney, and S.O. Serna-Saldivar, "The millets". Food Science and Technology: Handbook of Cereal Science and Technology, CRC Press. vol. 99, pp. 177-210, 2000.

[33] P. Singh, and R.S. Raghuvanshi, "Finger millet for food and nutritional security'. Afr. J. Food Sci. 6,77-84, 2012.

[34] M.K. Agnihorti, and U.K. Pall, "Quality of chevon sausage in refrigerated storage”. India J. Anim. Sci. vol. 15, pp. 69-73, 2000. 
[35] P.D. Warris, "Fats fatty acids in meat". In: meat science, an introductory Text $\left(2^{\text {nd }}\right.$ Edition). $C A B$ International, Wallingford Oxfordshire, UK, 2010.

[36] R.A. Lawrie, and D.A. Ledward, "The eating qualities of meat". In: Lawrie's Meat Science, (7th edition) Woodhead Publishing Limited, Abington Hall, Cambridge, England, 2006.

[37] R.A.A. Ranathunga, B.C. Jayawardena, and G.T.N. Gunasekara, "Effect of different extenders on physical, chemical and sensory characteristics of sausage production', Int. J. Inform. Res. Rev. vol. 2, pp. 1311-1314, 2015.

[38] Institute of Medicine, Food and Nutrition Board. "Dietary Reference Intakes: Calcium, Phosphorus, Magnesium, Vitamin D and Fluoride external link disclaimer', Washington, DC: National Academy Press, 1997.

[39] MedlinePlus. "Magnesium in diet". [Online]. Available: $\mathrm{https} / / /$ medlineplus.gov/ency/article/002423.htm (accessed on 23/08/2020), 2020.

[40] C. Shaffer, "Iron functions in the body". [Online] Available: https://www.news-medical.net/health/Iron-Functions-in-the-Body. aspx\#: :text=Iron $\% 20$ performs $\% 20$ many $\% 20$ important $\% 20$ function s, body\%20in\%20its\%20 free\%20state (accessed on 23/08/2020), 2020.
[41] B. Behailu, and M. Abebe, "Effect of soybean and finger millet flours on the physicochemical and sensory quality of beef meat sausage", Asian J. Chem. Sci. vol. 7, pp. 6-14, 2020.

[42] S. Ibrahim, "Utilization of wheat germ flour in the processing of sausage', Khartoum University, 2008.

[43] G.A. Teye, M. Teye, and G. Boamah, "Effect of cowpea (Vigna unguiculata) flour as an extender on the physico-chemical properties of beef and hamburgers', Afri. J. Food, Agric. Nutrit. Develop. vol.12, p.7021, 2012 .

[44] O.E. Evranuz, "The effects of temperature and moisture content on lipid peroxidation during storage of unblanched salted roasted peanuts: shelf life studies for unbranched salted roasted peanuts'. Int. J. Food Sci. Tech. vol. 28, pp. 193-199, 1993.

[45] M.T. Kamara, I. Amadou, and H.M. Zhou, "Antioxidant activity of fractionated foxtail millet protein hydrolysate' . Int. Food Res. J. vol. 19, pp. 59-66, 2012

[46] G.A. Teye, E.K. Owusu, and J. Nyasordzi, "Cowpea flour as nonconventional filler in comminuted beef and pork frankfurter sausages. Ghanaian',. J. Anim. Sci. vol. 4, pp. 39-45, 2009.

[47] O.P. Malav, B.D. Sharma, S. Talukder, and R.R. Kumar, "Economics of preparation of restructured chicken meat blocks extended with different vegetative extenders', J. Food Process. Technol. vol. 4, p. 282,2013 . 